\title{
Profesjonsidentitet i et flerkulturelt helsevesen Paradokser, grenser og ambivalens
}

\author{
Inger Daae-Qvale: \\ Inger.Daae-Qvale@hioa.no \\ høgskolelektor \\ Institutt for internasjonale studier og tolkeutdanning \\ seksjon Flerkulturelle studier \\ Høgskolen i Oslo og Akershus.
}

\footnotetext{
Keywords:

equality and diversity

construction of professional discourse

raising awareness of professional self-understanding; and implementation of multicultural competence.
} 


\begin{abstract}
Healthcare professionals are trained to "do good". Their role is to fulfil the welfare state's objective of curing or alleviating health problems among the population. The training of healthcare professionals is oriented towards the acquisition of comprehensive knowledge and is designed to make them authorities on the management of suffering. Traditionally the healthcare professions have adhered to strict ethical standards, where- among other thingsconcepts of equality and solidarity are intended to protect weak and marginalized groups. These ethical standards are also reflected in the official descriptions of their own roles promulgated by the health professions. An increasingly multicultural population has displayed demographic differences in disease incidence as well in cultural attitudes about health, disease and treatment. Service users from minority backgrounds are often categorized as problematic in the sense that they are not perceived as falling into a recognizable user category. These differences seem to create asymmetry in the professional field, due to lack of sufficient experience by health personnel or a lack of comprehensive knowledge about the appropriate handling of the group. This may create ambivalence in the professional practice of health personnel. I argue that health personell need to strengthen their multicultural competence to meet the healthcare needs of immigrant populations. The aim of the article is to contribute to a more thorough understanding of why healthcare professionals identity are challenged when they interact with a multicultural population. The article's method is based on discourse analytical persepectives through analyses of 31 text examples from health personell who strengthen their multicultural competence through education.
\end{abstract}




\section{Innledning og problemstilling}

Tema for denne artikkelen er profesjonsidentitet $\mathrm{i}$ et flerkulturelt helsevesen. Artikkelen retter søkelys mot profesjonsutfordringer som synes å vokse frem i kjølvannet av flerkulturell kompetanseheving i profesjonsfelt, og målet er å beskrive institusjonelle prosesser som oppstår når flerkulturelle brukergrupper tar plass i norsk helsevesen.

Med en økende flerkulturell befolkning oppstår demografiske forskjeller i sykdomsforekomst så vel som kulturelle uttrykk for helse, sykdom og behandling (Kumar og Viken 2010, Østby m.fl. 2013, Nasjonal strategi om innvandrerhelse 2013 - 2017, Helse- og omsorgsdepartementet 2013). Når disse forskjellene møter et etablert helsevesen, skaper de uorden i helsevesenets klassifiseringssystem. Brukergrupper med minoritetsbakgrunn blir ikke gjenkjent i helsevesenet på samme måte som brukergrupper med majoritetsbakgrunn. Manglende gjenkjennbarhet kan medføre at helsepersonell ikke klarer å identifisere minoritetspasienters behandlingsbehov, med den konsekvens at pasientene ikke får behandlet eller lindret sine helseproblemer. En årsak til at behandlingsbehov ikke blir identifisert, kan ha sammenheng med manglende flerkulturell kompetanse hos helsepersonell.

Artikkelen er en respons på myndighetenes målbæring av etnisk likestilling $\mathrm{i}$ offentlig tjenesteyting (Stortingsmelding nr.17 1996-97, Stortingsmelding nr. 49 2003-20049, Stortingsmelding nr. 6 2012-2013). Ett sentralt virkemiddel for å nå målet om etnisk likestilling, er heving av den flerkulturelle kompetansen i og gjennom utdanningssystemet. Institutt for internasjonale studier og tolkeutdanning ved Høgskolen i Oslo og Akershus har siden 1997 gitt ulike utdanningstilbud for å styrke flerkulturell kompetanse hos offentlige tjenesteytere. To av studiene har mange studenter med helsefaglig bakgrunn, og i denne artikkelen er empirien hentet fra tekster skrevet av helsepersonell ved disse studiene.

Mange studenter ved de flerkulturelle studiene gir uttrykk for at de møter problemer med a implementere sin flerkulturelle kompetanse i eget fagmiljø. Kompetansen medfører for manges del at de tildeles rollen som «flerkulturell ekspert» og samtidig blir pålagt ansvar for håndtering av fagmiljøets flerkulturelle virkelighet. Opplevelsen av å bli definert som institusjonens flerkulturelle alibi skaper frustrasjon, faglig ensomhet og forventningspress om å løse arbeidsstedets flerkulturelle problemstillinger.

Parallelt med flerkulturelle utdanningstilbud pågår det i mange helseforetak et internt arbeid for å styrke profesjonsutøveres flerkulturelle kompetanse (Helse- og omsorgsdepartementet 2013). Men til tross for mange års satsning på å styrke mangfoldkompetanse i helsevesenet, synes det likevel å være en motstand i fagmiljøer som bidrar til et gap mellom idealer om mangfoldhåndtering på den ene siden, og fravær av tid og ressurser til reell implementering av denne kompetansen på den andre siden (Raaen 2003, Leseth og Solbække 2011, Sandbæk mfl. 20012, Rogstad og Solbrække 2012).

En konsekvens av dette kan bli at helsepersonell inntar ulike faglige tilnærminger i møte med minoritetspasienter, noe som kan medføre usikkerhet og lojalitetskonflikter mellom kolleger i spørsmål om hvordan brukere med minoritetsbakgrunn skal forstås og behandles.

Det å mestre behandlingsbehov hos flerkulturelle brukergrupper synes derfor å forutsette at helsepersonell har en felles forståelse av hvordan kultursensitive problemstillinger skal håndteres. Dette reiser spørsmål om hvordan krav om flerkulturell kompetanse faktisk forstås og implementeres i helseforetak. Forfatteren vil i denne artikkelen søke å gi noen svar på dette gjennom en drøfting av følgende spørsmål: Hvordan påvirker flerkulturell fagutvikling helseprofesjoners selvforståelse? Hvordan utfordrer flerkulturelle brukergrupper helsepersonellets etablerte helsediskurs? Spørsmålene berører flerkulturelle sam- 
handlingsrelasjoner så vel som faglig virksomhet og institusjonelle strukturer i et flerkulturelt helsevesen.

I artikkelen presenteres først et teoretisk og analytisk rammeverk som danner grunnlag for dataanalyse av det empiriske materialet. Deretter følger presentasjon og analyse av de empiriske funnene.

\section{Teoretiske perspektiver}

Artikkelens tema, håndtering av profesjonsidentitet i et flerkulturelt helsevesen, berører ulike sider ved forskjellige typer profesjonsvirksomhet. En måte å forstå profesjoner på er som sosiale fellesskap som utfører faglig virksomhet slik de er vedtatt eller autorisert av offentlige myndigheter. Profesjonsvirksomhet er forankret i faglig ideologi, og profesjonsutøverne sosialiseres inn $\mathrm{i}$ en bestemt yrkespraksis gjennom verdier, normer og koder knyttet til denne ideologien. Profesjonsidentiteten formes gjennom teoretiske og praktiske (ut)danningsprosesser. Profesjons(ut)danninger har som felles kjennetegn at de er systematisk innrettet mot ulike yrkesfelt, med nærhet til praksis og til klient- og pasientbehov (Slagstad 2008:65).

Profesjonsfelt kan betraktes som kunnskaps- og maktfelt i den forstand at de er etablert gjennom ulike grunnbegrep som avgrenser fagfeltet utad. Innad i profesjonenes fagfelt pågår det til enhver tid ulike former for kommunikasjon om hva som skal være faglige anerkjente verdier, hva det skal herske uenighet om og hva som skal være utillatelig for profesjonens virksomhet. Profesjoner kan dermed forstås som diskursive systemer der blant annet spenningsfeltet mellom vedlikehold og endring bidrar til faglig og organisatorisk samhandling (Eriksen 2001, Molander og Terum 2008). Reglene som etablerer og styrer profesjonene synes alltid à ha sterke krav om felles kommunikasjon internt $\mathrm{i}$ fagfeltet. Dersom reglene trues eller brytes, endres også premissene for fagfeltets indre diskurs (Foucault 1999, Eriksen 2001, Grimen 2008, Heggen 2008, Scollon m.fl. 2012). Forstått på denne måten uttrykker profesjonsidentitet en kollektiv faglig identitet som kan kobles opp mot en etablert faglig orden innad i et profesjonsfelt (Heggen 2008, Grimen 2008).

Samtidig har profesjoner faglig autonomi. Dette innebærer en viss frihet til å handle etter profesjonens egne faglig begrunnede normer ved at profesjonsutøveren gis mulighet til å utøve faglig skjønn, og å handle etter egen vilje innenfor de mål og retningslinjer som gjelder for den virksomheten hun eller han er tilsatt i (Eriksen 2001, Grimen 2008). Denne friheten gir rom for profesjonsutøverens bruk av personlige egenskaper. Hvordan den profesjonelle forstår seg selv som profesjonsutøver utvikles gjennom en individuell profesjonsstil der profesjonens krav kobles mot egen personlighet (Hansbøl og Kreisler 2004:31).

Videre er helseprofesjonenes virksomhet praksisnær, med sterk vektlegging på språk og handling. Helsepersonell kaller ofte sin profesjonsutøvelse for praksis. Praksis representerer konteksten som helseprofesjoner kommuniserer sitt faglige handlings- og meningsunivers gjennom (Grimen 2008). Praksisdimensjonen refererer i denne artikkelen til kroppsliggjorte og kommunikasjonsmessige ferdigheter som dannes gjennom profesjonsstudier. Helseprofesjonenes pleie- og behandlingstiltak utrykkes gjennom gjøremålsrettet virksomhet. «Å gjøre noe» med eller for pasienten/klienten/brukeren, er en måte å forstå og omtale sin yrkesmessige habitus på. Handlingsorientering utgjør med bakgrunn i en slik forståelse en sentral dimensjon i helsepersonells profesjonsidentitet.

Fagutvikling $i$ institusjoner kan forstås som prosesser der endring og omstilling gjøres relevant. Styrking av flerkulturell kompetanse forstås som slik fagutvikling. Krav om endring og omstilling vil gjerne medføre at etablerte faglige og sosiale mønstre utfordres. Faglige og 
sosiale mønstre i profesjoner skapes av profesjonens egne aktørers valg og samhandling. Ved å rette blikket mot det som skaper sosiale mønstre mener sosialantropologen Fredrik Barth at det er realistisk å anta at man kan påvirke mønstre (Barth 1994). Artikkelens søkelys på hvordan sosiale mønstre skapes og kommuniseres $i$ et flerkulturelt helsevesen kan forhåpentligvis bidra til å bevisstgjøre hvordan helseprofesjoner definerer og forstår sin profesjonsidentitet i møte med flerkulturelle brukergrupper. Bevisstgjøring av egen profesjonsidentitet kan videre bidra til dypere innsikt i prosesser som åpner opp for - eller hindrer implementering av flerkulturell fagkompetanse i profesjonsfelt.

\section{Metodisk og analytisk tilnærming}

Analysen i denne artikkelen er basert på diskursanalytiske perspektiver. En diskursanalytisk tilnærming innebærer å studere hvordan mening skapes og konstrueres i vid forstand, og hvilken betydning bestemte verdensbilder har på våre sosiale liv (Jørgensen og Phillips 1999, Hitching m.fl. 2011). I artikkelen refererer «sosiale liv» til institusjonelle praksiser slik disse skapes i skjæringspunkt mellom menneskelig samhandling og faglige og institusjonelle strukturer. Kontekst gis en sentral betydning i analysen, og kan forstås «som et sett av rammer som omslutter den sosiale hendelsen som blir studert» (Hitching og Veum 2011:27). Kontekst refererer videre til to dimensjoner: På den ene siden til en situasjonskontekst som er praksis der profesjonsutøvelse (hendelser) finner sted. På en annen side er rammene for praksis forbundet med en mer overordnet, institusjonell og sosiokulturell sammenheng som utgjør profesjonsutøveres diskursive referansegrunnlag (verdigrunnlag). Gjennom ulike former for kommunikasjon speiler profesjonsutøvere hvilke verdier som skal ha gyldighet i profesjonens helsediskurs. Språk bidrar blant annet til à ytre opplevelser av mening, og språkets spontane uttrykk kan ofte speile hva vi kan forbinde oss med - relasjonelt og situasjonelt. Ved å studere hvordan mening kommer til uttrykk gjennom samhandling og kommunikasjon $\mathrm{i}$ et profesjonsfellesskap som håndterer flerkulturelle problemstillinger, kan en diskursanalytisk tilnærming bidra til å forstå håndteringen av profesjonens flerkulturelle faglige utfordringer.

Profesjonsfeltet der studentenes tekster og samhandlingsrelasjoner gjøres til gjenstand for analyse kan forstås som et sosialt felt. Pierre Bourdieu anvender begrepet «sosialt felt» for analytisk å avgrense en del av en større sosial enhet i den hensikt å studere feltet empirisk (Bourdieu 1995). Et sosialt felt er i sin opprinnelse definert til å være et sted hvor mennesker samles i en forent tro på hvilke førende verdier som skal være det gode (det som skal ha forrang). I et felt som bruker verdi som målestokk på rangering, vil det ifølge Bourdieu (1995) pågå en kamp om posisjoner. Studentenes tekster slik de undersøkes i denne artikkelen, viser hvordan menneskelige og faglige egenskaper i flerkulturell klinisk samhandling stadig diskuteres og fortolkes. Ulike oppfatninger av hvordan flerkulturell samhandling bør forstås kan relateres til pågående strategier om hvilke synspunkter som skal ha gyldighet i håndtering av flerkulturelle brukere. Bourdieu (1995) hevder også at vedvarende strategier og motstrategier for å skape dominans innad i ulike felt nødvendigvis vil være knyttet til ulike former for makt. Posisjonene kan fremstå som gjensidige og inkluderende størrelser, men kan også representere det motsatte i den forstand at de kommuniserer underkjenning og ekskludering. I et klinisk samhandlingsperspektiv kan dette innebære at kolleger som ikke følger etablerte handlingsmønstre, kan stå i fare for å bli ekskludert som gyldige fagutøvere. 
Studentene uttrykker samtidig at brukere med minoritetsbakgrunn ofte gjøres til gjenstand for diskriminerende og fordomsfulle beskrivelser fra helsepersonell. Det å definere andres egenskaper beskrives $i$ et kritisk diskursanalytisk perspektiv som definisjonsmakt, i kraft av evne eller rett til å bestemme hvordan et fenomen eller gruppe skal avgrenses eller omtales (Grue 2011:116). Denne type definisjonsmakt er ofte anvendt i omtale av mennesker som representerer former for annerledeshet. Eksempler på dette kan være personer med funksjonsnedsettelse, homofil eller lesbisk legning, eller etnisk opphav. I kraft av sin annerledeshet tillegges gruppene en form for utenforskap som i mange situasjoner omtales diskriminerende eller fordomsfullt (Grue, 2011:116-120).

Ved at helsepersonell som offentlige tjenesteytere definerer flerkulturelle brukergruppers egenskaper gjennom en negativ språksjanger, øker risiko for problemorientering og marginalisering av gruppen. En etisk utfordring ved å ta tak i språklige formuleringer som omhandler konfliktfylte forhold $\mathrm{i}$ et fagmiljø, kan innebære at kolleger $\mathrm{i}$ et fagfelt opplever at de gjøres til gjenstand for negativ omtale. Samtidig kan slik forskning ha som formål å øke bevisstheten om språkbruk gjennom kritisk refleksjon over egen faglig praksis (Fairclough 1992a:239). Halvard Vike hevder at når vi arbeider med offentlige problemstillinger handler det om informasjon som vedrører offentlig liv. I slike sammenhenger er det relativt sjelden at vi interesserer oss for informasjon som er genuint privat. Empirien i artikkelen omhandler blant annet helsepersonells kommunikasjon som offentlige tjenesteytere. Kommunikasjonen er knyttet til flerkulturelle problemstillinger i profesjonsutøvelse, og det er sviktende profesjonalitet som gjøres til gjenstand for diskusjon i studentenes tekster og i artikkelen. Når sviktende profesjonalitet som fenomen skal beskrives, er det nødvendig å løfte temaet opp til et nivå som berører strukturer, posisjoner og samspill i institusjonen - i den hensikt å forstå hvordan fenomenet kan oppstå, og hva det er uttrykk for. Vike (2001) viser til at konfliktfylte temaer kan være sensitivt stoff, men i et samfunn med en åpen offentlighet må det være slik at både positive og negative funn kan gjøres til gjenstand for offentlig diskusjon.

\section{Data og analysegrunnlag}

Artikkelens empiriske grunnlag er hentet fra 31 tekster skrevet av studenter som har gjennomført flerkulturelle studier ved Institutt for internasjonale studier og tolkeutdanning, Seksjon for flerkulturelle studier ved Høgskolen i Oslo og Akershus. Tekstene er hentet fra fire forskjellige kull. I løpet av studiet skriver studentene to refleksjonsnotat der de skal formulere aktuelle problemstillinger knyttet til flerkulturell samhandling i eget profesjonsfelt. Samhandlingen kan være rettet mot kollegarelasjoner eller profesjonsutøvere i samspill med flerkulturelle brukergrupper. I tillegg til å skrive refleksjonsnotater har studentene obligatorisk deltagelse i eget diskusjonsforum som foregår i studentenes digitale læringsrom (Fronter). Faglærer formulerer aktuelle problemstillinger fra samlingene, eller et aktuelt samfunnstema som berører flerkulturelt samspill. Målet med kravet til skriftlige fremstillinger er at studentene skal lære å reflektere kritisk over egen praksis. De skriftlige arbeidskravene i studiet har som pedagogisk formål å styrke studentenes evne til $\stackrel{\circ}{a}$ argumentere for sin profesjonelle håndtering av flerkulturelle problemstillinger. Studentene skal kunne begrunne sine analyser og drøftinger med referanser til pensumlitteratur eller annen teoretisk forankring. Faglærer veileder skriftlig på refleksjonsnotater og i forumdiskusjoner.

Studentene har gitt skriftlig samtykke til at tekstene kan brukes i denne artikkelen. Studentenes sitater er gjengitt i sin originale versjon. Studentenes tekster er anonymisert, slik at personer og hendelser ikke kan gjenkjennes. Studentene har rett til å oppheve sitt samtykke, men til nå har ingen benyttet seg av denne retten. Studentene har bakgrunn 
som sykepleiere, vernepleiere, radiografer, stråleterapeuter, ergoterapeuter og fysioterapeuter. De blir omtalt som studenter, helsepersonell og profesjonsutøvere i den videre teksten.

Funnene ble systematisert og plassert i ulike kategorier når de skulle analyseres.

For det første er valg av kategorier foretatt med bakgrunn i studentenes subjektive erfaringer i flerkulturell samhandling. Disse erfaringene beskrives i mange tekster som faglig ensomhet, avmakt, motstand, profesjonsforpliktelse, motivasjon og faglig fellesskap. Studentenes beskrivelser tolkes av forfatteren som erfaringer knyttet til studentenes profesjonsidentitet og profesjonstilhørighet. De synes å speile hva studentene forbinder seg med som profesjonsutøvere både relasjonelt og situasjonelt (Jørgensen og Phillips 1999, Hitching m.fl. 2011). De beskriver både negative og positive erfaringer i et flerkulturelt fagmiljø.

For det andre er kategoriene konstruert med bakgrunn i profesjonenes institusjonelle praksiser som er skapt i skjæringspunkt mellom faglige og institusjonelle strukturer og menneskelig samhandling. Institusjonelle praksiser i lys av profesjonsteorier og profesjonsdiskurser har bidratt til inspirasjon i utforming av kategorier, med særlig vekt på profesjoner som organiserte, faglige og sosiale fellesskap og profesjoner som makt og kunnskapsfelt ( Bourdieu 1995, Foucault 1999, Grimen 2008, Heggen 2008). Tekstene som utgjør datamaterialet er analysert opp mot fire kategorier:

- Profesjonsidentitet og flerkulturell samhandling

- Profesjonslojalitet og ambivalens

- Vedlikehold av profesjonsdiskurser gjennom immunisering av praksis

- $\quad$ Flerkulturelle virkeligheter og profesjonell selvrefleksjon

\section{Profesjonsidentitet og flerkulturell samhandling}

I de ulike profesjonsfeltene studentene arbeider $\mathrm{i}$ pågår det med jevne mellomrom diskusjoner om hvordan flerkulturelle brukergrupper skal fortolkes og forstås når de samhandler med helsepersonell. Hvilke egenskaper som tillegges brukere med minoritetsbakgrunn synes å være forbundet med hvordan brukergruppen tilpasser seg behandlingstilbudet $i$ et norsk helsevesen. Brukere som tilpasser seg foreskreven behandling oppleves som «greie pasienter». Men hva skjer dersom brukere ikke følger opp foreskreven behandling? Hvordan helsepersonell reflekterer over dette synes å være knyttet til brukerens egenskaper og ikke til samhandlingen mellom helsepersonell og bruker, der også helsepersonellets egenskaper synliggjøres. Studentene beskriver at de i liten grad er vant til å reflektere over egen profesjonsrolle - «jeg tenker ikke over det, for jobben går liksom av seg selv», skriver en student. Gjennom de flerkulturelle studiene utfordres studentene til profesjonell selvrefleksjon. For å kunne håndtere flerkulturelle problemstillinger i praksis er bevisstgjøring av egen og andres virkelighetsforståelse et sentralt aspekt. En av studentene formulerer egne erfaringer knyttet til sin kulturelle og profesjonelle selvrefleksjon på denne måten: 
Da jeg begynte på studiet var jeg opptatt av å lære om innvandrere og ble litt forvirret når læreren sa at dette studiet handler like mye om å bevisstgjøre hvordan du som profesjonsutøver forstår deg selv, både $i$ en kulturell og profesjonell

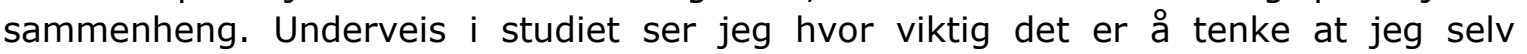
kommer et sted fra, og at jeg handler ut i fra å ha vokst opp og tatt sykepleierutdanning i Norge. Selv om jeg har somalisk bakgrunn og kom hit som lite barn har studiet gjort meg bevisst på at jeg er ganske lik nordmenn i måten å være på. Det har jeg ikke tenkt over før, men studiet har også gjort meg bevisst på at den måten jeg er sykepleier på har sin bakgrunn i en norsk utdanning.

Heggen (2008) beskriver profesjonsidentitet som en kollektiv identitet formet gjennom utdanning. Profesjonsutøvere trenes til å kommunisere felles verdier både gjennom utdanning og i senere profesjonsutøvelse. Den internaliserte kunnskapen blir i en viss forstand automatisert; de enkelte utøverne reflekterer sjelden over hvorfor de handler og tenker som de gjør. Studentens beskrivelser over at hun ikke har tenkt over hvor lik hun er nordmenn i måten å være på, kan vise tilbake til diskursive betingelser i egen kulturell bakgrunn så vel som den fagdiskursen hun er en del av. Som oppvokst i Norge er hennes virkelighetsforståelse preget av meningsdanning som kan knyttes til en norsk kulturkontekst. Pasientgrupper som tilpasser seg behandling, er på samme måte som helsepersonell sosialisert inn i den norske helsediskursen (Ingstad 2007). De kjenner til hvilke rammer og ritualer som gjelder i diagnostisk og behandlende virksomhet, og de mestrer kommunikasjonen av den norske helsediskursen. Det er først når pasienter ikke følger opp foreskreven behandling at det blir brudd $i$ en felles «tatt for gitt» -kommunikasjon mellom helsepersonell og brukergrupper. Det at helsepersonell utfordres av pasienter som ikke følger behandlingsinstrukser kan samtidig være en indikasjon på at kommunikasjonen mellom helsepersonell og pasient skjer på helsepersonellets premisser premisser som kan ha utspring i etablerte fagstrukturer i profesjonsmiljøet. En student uttrykker dette slik:

Jeg har blitt bevisst på at yrkesidentiteten min er formet innenfor gitte rammer. Som profesjonsutøver ønsker jeg å innordne meg reglene og normene på arbeidsplassen.

Utsagnet viser at studenten gjennom profesjonell selvrefleksjon har blitt seg bevisst hvordan hennes profesjonsidentitet har blitt formet. Samtidig gir hun uttrykk for et ønske om å vise lojalitet og innordne seg den etablerte profesjonspraksisen hun er medlem av gjennom å vedlikeholde regler og normer som arbeidsplassen har definert som gyldige. Studentens utsagn illustrerer at profesjonens utdanningsinnhold og institusjonsstrukturer sammen med profesjonsutøverens egen kulturkontekst på ulike vis har bidratt til à konstituere helsepersonells forståelse av egen profesjonsorden (Heggen 2008, Hitching og Veum 2011:28).

Allerede som student i helseprofesjonsutdanninger kan studenter blir møtt med krav om à innordne seg profesjonsfeltets indre diskurs:

Jeg har ofte sett det i praksis når særlig de som er nyutdannet kommer med synspunkter på hvordan dette og hint kan gjøres på andre måter. De møter motstand og får høre at «sånn gjør vi det her, og sånn tenker vi å fortsette å gjøre det!». A bli møtt med slik motstand og misnøye vil kunne føre til at man blir mer utrygg i sin profesjon, og ikke tør å tenke nytt, og man ender lett opp med å bli «formet inn» i en eksisterende praksis. Man kan også komme i fare for å bli utstøtt, neglisjert, bli sett 
på som bedreviter, noe som igjen kan føre til at man selv får det psykisk vanskelig på jobb.

Nyutdannet helsepersonell synes tidlig å lære at det å utfordre eksisterende praksis i forsøk på å endre verdier og normer som er etablerte, ikke blir tatt godt imot. Vedlikehold av profesjonspraksis håndheves gjennom kollektive krav til lojalitet, noe som gir signaler om hva slags klinisk samspill den enkelte skal slutte seg til. Studentene som har styrket sin flerkulturelle fagkompetanse møter det samme kravet om å underkaste seg en etablert profesjonspraksis på lik linje med nyutdannede studenter som foreslår endringer i etablerte praksisfelt. En student beskriver hvor vanskelig det kan være å stimulere kolleger til å ta inn over seg ny kunnskap for å møte flerkulturelle brukergruppers behov:

Etter som samfunnet blir mer flerkulturelt byr dette på utfordringer i vår avdeling. Vi får flere pasienter med innvandrerbakgrunn. Vi blir tvunget til å se på utøvelse av praksis med nye øyne, og tilegne oss økt kompetanse om mennesker med en annen bakgrunn enn oss selv. Men det er ikke lett å skape interesse hos kollegene, jeg blir ofte møtt med motstand under dekke av mangel på ressurser og krav om effektivitet, sagt med andre ord: dette har vi ikke tid til, eller i verste fall: dette har vi ikke bruk for. Det er ikke lett.

Slik studenten beskriver sine erfaringer med å skape rom for flerkulturelle brukergrupper, så uttrykker studenten at egen faglig tilnærming skaper konflikt mellom en felles profesjonsidentitet og egen profesjonell identitet. Studentens utsagn illustrerer Heggens (2008) distinksjon mellom to typer fagidentitet hos profesjonsutøvere, både en profesjonsidentitet og en profesjonell identitet. Profesjonsidentitet og profesjonell identitet kan forstås som både et sammenfallende og et kontrasterende fenomen (Heggen 2008:325). Hva det vil si å være en profesjonell har ifølge Heggen utspring i profesjonsutøverens egen kulturkontekst i tillegg til det utdanningsinnhold og de institusjonsstrukturer som på ulike vis bidrar til å konstituere helsepersonells forståelse av egen profesjonsorden (Heggen 2011:328).

Profesjonsidentitet er tosidig. På den ene siden er den en kollektiv identitet, formet gjennom utdanning og yrkesutøvelse i fagfeltet (Heggen 2008:231, Scollon m.fl. 2012). Sosialiseringen inn i yrkespraksis er forankret i gitte verdier, normer og koder som skaper et avgrenset kunnskaps- og maktfelt utad. Reglene som etablerer og styrer profesjonen har sterke krav om felles kommunikasjon innad i fagfeltet. Slike sterke krav kjennetegnes ved en reproduserende og vedlikeholdende profesjonspraksis. Dersom slike etablerte regler trues eller brytes, endres også premisser for fagfeltets indre diskurs (Foucault 1999, Eriksen 2001, Molander og Terum 2008, Scollon m.fl. 2012:180 -201). Den kollektive profesjonsidentiteten synes å hvile på en viss rigiditet som utfordres gjennom prosesser der forholdet mellom profesjon og endring gjøres gjeldende (Molander og Terum 2008:13).

På den andre siden åpner bruk av skjønn opp for egen faglig autonomi. Gjennom bruk av skjønn kan profesjonsutøvere handle etter egen vilje innenfor de mål og retningslinjer som er fastsatt for det enkelte profesjonsfelt. Ny faglig innsikt, slik flerkulturell kompetanse erfares hos studentene, åpner for nye måter å forstå pleie- og behandlingsbehov hos brukergrupper med flerkulturell bakgrunn. En student beskriver hvordan hun selv anvender skjønn for å gi brukergrupper et godt behandlingstilbud: 
Samtidig mener jeg at det ikke er ok å utføre en oppgave på en bestemt måte bare fordi "det alltid har vært sånn." I arbeidet med flyktninger har jeg erfart at jeg må ta andre grep, de har ikke alltid oversikt over hvordan helsevesenet vårt er bygget opp. Jeg må utøve skjønn, men det oppstår lett konflikter når kolleger sier at flyktningene ikke skal behandles annerledes enn norske brukergrupper.

Gjennom bruk av skjønn har profesjoner muligheter til å gjøre valg i en handlingssituasjon (Eriksen 2001, Grimen 2008). Bruk av skjønn omhandler blant annet å bruke egne ressurser, evner, kunnskaper og verdier i møte med brukergrupper. Samtidig åpner muligheten for bruk av skjønn opp for en subjektiv forståelse av situasjoner:

Motivasjonen for å delta i dette studiet var nettopp det å få mer kunnskap for å ha sterkere kort på hånden i diskusjoner om innvandrerpasientene. Jeg skulle ønske det ble en holdningsendring til pasienter med innvandrerbakgrunn. Jeg har kolleger som ofte sier: «Jeg blir så frustrert av flerkulturelle pasienter, de skjønner ikke behandlingsopplegget vårt. Uansett hvor mye jeg prøver å forklare hvorfor vi gjør som vi gjør her, så skal de bare gjøre det de vil.» Da jeg forsøkte å forklare at pasienten hadde en annen måte å forstå sykdommen sin på ble jeg stanset med følgende kommentar av en annen kollega: «La vær å forsvare disse, de får ikke oppføre seg slik på min avdeling, for sånt gidder jeg ikke.» Så blir det ikke sagt noe mer.

Denne forståelse for bruk av skjønn kan knyttes til det som Heggen (2008) beskriver som den enkelte utøvers profesjonelle identitet, og som ikke utelukkende er et resultat av profesjons(ut)danning. En profesjonell identitet er samtidig forbundet med den enkelte profesjonsutøvers kulturelle og sosiale bakgrunn. Heggen forstår dette som en personliggjøring av kunnskap, og mener at denne personliggjøringen vil være avgjørende for hvordan læreprosessen gjennom utdanning bidrar til å internalisere den enkeltes selvforståelse som profesjonsutøver og som profesjonell. Når denne skjønnsutøvelsen ikke korresponderer med den etablerte minoritetsdiskursen i det faglige fellesskapet, vil den i stedet fungere som kontrasterende (Heggen 2008:324).

Hva innebærer det for den enkelte å veksle mellom posisjonen å være én $i$ et fellesskap (individuell identitet $\mathrm{i}$ profesjonen) i motsetning til den enkeltes væren som en del av et fellesskap (kollektiv identitet i profesjonen)? Studentenes tekster viser at faglig uenighet kan skape dilemmaer og konflikt mellom den felles profesjonsidentiteten og egen profesjonell identitet.

Profesjonsutøveren som fremhever andre måter å forstå pasienten på gjennom bruk av skjønn, blir oppfattet som en som overskrider profesjonsfeltets grenser for hva som er tillatt og hva som er definert som utillatelig (Scollon m.fl. 2012). Kollegene i det ovenstående sitatet kommuniserer en forventning om at minoritetspasienter skal forstå «hvordan man gjør det her». Dersom minoritetspasientene ikke forstår, formidles et implisitt budskap om at helsepersonell skal stille krav til pasienten om å følge gitte behandlingsprosedyrer, $\mathrm{i}$ stedet for å forsvare flerkulturelle brukergrupper. Dette kan skape en lojalitetskonflikt når

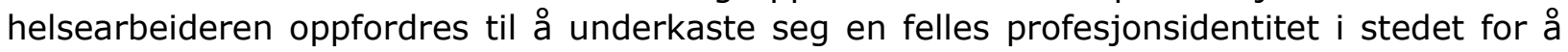
følge den faglige overbevisningen som kan hvile i den enkeltes profesjonelle identitet. 


\section{Profesjonslojalitet og ambivalens}

Manglende enighet innad i profesjonsfeltet om hvordan flerkulturelle brukergrupper skal håndteres, ser ut til å skape lojalitetskonflikter og ambivalens innad i fagfeltet. Studentene beskriver at det å påpeke flerkulturelle problemstillinger ofte kan bli avvist av kolleger. Slik avvisning oppleves for mange studenter som å bli utestengt faglig, noe som uttrykkes gjennom utsagn som at de som kolleger «trøbler det til i fagmiljøet» når de løfter frem flerkulturelle problemstillinger:

Vi var flere kolleger som hadde veiledning, og jeg tok opp situasjonen til en innvandrerfamilie som hadde problemer med grensesetting for barnet sitt. En av kollegene mine ble provosert og sa til meg: «Gi deg med alle disse sakene dine. De er så depressive og komplekse. Kan vi ikke heller ha noe lettere nå?». Vi var syv personer til stede og ingen av de andre sa noe.

Dette kan være illustrasjon på en gryende interessekonflikt innad i eget fagmiljø. Kolleger som tar opp andre synspunkter omkring faglige ferdigheter enn det som er definert som anerkjent, kan komme i konflikt med profesjonsfeltets interesse og makt. Det kan virke som en profesjonell identitet i kraft av et «jeg» kan komme i lojalitetskonflikt med profesjonsidentiteter i kraft av et kollektivt «vi» når ulike syn på behandling oppleves som motsetningsfylte (Eriksen 2001, Heggen 2008:324, Scollon m.fl. 2012).

Det at noen kolleger avfeier andre kollegers faglige problemstillinger som ugyldige, kan samtidig være et uttrykk for å kamuflere egen manglende handlingskompetanse i møte med flerkulturelle brukergrupper. Helsepersonell som velger en restriktiv og avvisende tilnærming i møte med flerkulturelle problemstillinger inntar i noen sammenhenger rollen som portvoktere - som en strategi for å unngå at egen tilkortkommenhet skal avdekkes (Vike 2001). En portvokterrolle kan eksponeres ved at noen i kollegiet tar definisjonsmakt over hvordan flerkulturelle brukergrupper skal håndteres, samtidig som de også tar kontroll over hvordan flerkulturelle problemstillinger skal defineres og gis plass i profesjonsfeltet. Helsepersonell velger ofte å være lojale mot hverandre og institusjonens rutiner - og de forventer samtidig lydighet fra brukergrupper. En student beskriver en slik lojalitetskonflikt på denne måten:

Noen ganger kan det være vanskelig å tie om det jeg mener er urett. Mange av kollegene mine er så problemfokusert og forutinntatt når det gjelder innvandrerpasienter. Men når jeg tar opp dette, så blir jeg møtt med taushet. Ja, noen kolleger blir fornærmet og viser til at her hos oss så skal alle behandles likt, de fremmedkulturelle skal ikke ha noe mer enn andre pasienter. Jeg står ganske alene. Men i tillegg så er det nå en gang sånn at for at en arbeidsplass skal være en trivelig plass å være, så vil man nødig skape dårlig stemning. Jeg mener ikke at man skal gå på akkord med seg selv og egne verdier. Men i virkelighetens verden så blir det ofte til at man "velger kampene sine med omhu".

Når helsepersonell tar flerkulturelle brukergrupper i forsvar, opplever de at de viser solidaritet med svake og marginaliserte brukergrupper, noe som er i tråd med yrkesetiske verdier (Eriksen 2001, Grimen 2008). Samtidig kan det å ta svake grupper i forsvar oppleves som forsøk på å korrigere kolleger som har stereotype og fordomsfulle forestillinger om minoritetsgrupper, og bli oppfattet som fornærmende handlinger overfor kolleger. En konsekvens av dette kan bli at de som prøver å rette et kritisk blikk mot egen praksis, og som våger å bringe inn nye tanker og premisser for å mestre et flerkulturelt 
fagmiljø, selv står i fare for å bli marginalisert - eller ekskludert (Vike 2001, Båtnes 2006, Daae-Qvale 2006, 2009). Gjennom slike hendelser synes flerkulturelle problemstillinger å få svekket gyldighet i profesjonsfeltet. Manglende anerkjennelse av flerkulturell kompetanse for à ivareta flerkulturelle brukergruppers helse og behandlingsbehov blir gjennom marginalisering et nedprioritert kompetanseområde. Dette er i tråd med tidligere studier som har vist at flerkulturell kompetanse i fagfelt ikke har høy faglig status, noe som kan forklare en av grunnene til at implementering av flerkulturell kompetanse kan være tungt å gjennomføre (Raaen 2002, Daae-Qvale 2006, 2009, Sandbæk m.fl. 2012).

\section{Vedlikehold av profesjonsdiskurser gjennom immunisering av praksis}

Praksisfeltet er det stedet hvor helsepersonell samhandler med hverandre og med brukergrupper. «Som helsepersonell er det praksis jeg identifiserer meg med», skriver en student. Med andre ord: Det jeg gjør, er den jeg er som profesjonsutøver. Utsagnet bekrefter at profesjonsutøvelse er tett forbundet med en sterk handlingsorientering (Grimen 2008). I foregående avsnitt ble handlingsorienteringen også forbundet med et krav om å følge etablert praksis. Studentene beskriver hvordan det å «gjøre likt» i det kliniske samspillet gir opplevelse av faglig fellesskap, noe som igjen styrker den kollektive profesjonsidentiteten:

Jeg var i ferd med $\stackrel{\circ}{a}$ forberede en pasient til røntgenundersøkelse av lungene. Pasienten som var en eldre kvinne fra Pakistan, snakket dårlig norsk. Det tok tid før hun forsto hva jeg mente med mine instruksjoner om når hun skulle holde pusten og når hun kunne puste ut igjen. En av kollegene mine ble irritert fordi jeg brukte for lang tid på pasienten og utbrøt: «Slik kan vi ikke holde på med norske pasienter, vi blir aldri ferdige her i dag hvis du skal ta så mye hensyn til denne innvandreren. Her skal alle behandles likt. Vi skal ikke ha noen forskjellsbehandling med de flerkulturelle. De må skjønne at slik gjør vi det her. Det heter å innrette seg».

Det å gjøre likt kan også forstås som en måte og opprettholde og vedlikeholde en opplevelse av felles faglig trygghet. Dette synes særlig à gjelde i situasjoner hvor profesjonsutøvere ikke mestrer håndtering av flerkulturelle problemstillinger. Manglende mestring kan oppleves som at profesjonsfeltets diskursive grenser trues. Brukere med minoritetsbakgrunn som ikke tilpasser seg helsevesenets behandlingsrutiner, blir ofte anklaget for å teste praksisfeltets grenser, eller at de ikke viser respekt for helsepersonell. Følgende situasjon finner sted $\mathrm{i}$ en avdeling:

På infeksjonsavdelingen hos oss ble det lagt inn en eldre kurdisk mann med lungelidelse. Han ble isolert da det var mistanke om smittsomme bakterier. Vi informerte pårørende om bruk av smitteutstyr ved å vise hvordan de skulle kle på seg, og hvordan de skulle behandle det etter bruk. Noen pårørende snakket norsk og de sa de forsto alvoret i pasientens situasjon. Men hva skjedde? Munnbind og frakker lå over alt, og barn lekte inne hos pasienten og i gangene. Frustrasjonen vår økte fordi vi ikke ble tatt på alvor. Jeg oppfattet det som provoserende, den familien viste ingen respekt for oss og testet grenser. I et forsøk på å snakke de til rette enda en gang ble jeg kalt rasist.

Helsepersonells fagautoritet synliggjøres gjennom samspill med brukergrupper og kolleger. Helsepersonell er synlige i det offentlige rom, og det er knyttet sterke forventninger til à tilfredsstille brukeres behandlingsbehov. Kommunikasjon med brukergrupper og kolleger skjer for det meste gjennom ansikt-til-ansikt-relasjon. Det er med andre ord tilskuere til 
stede når profesjoner utøver sin fagkompetanse. Relasjonelt samspill gjennom synlighet og tilstedeværelse medfører samtidig at profesjoner er utsatt for risiko. Manglende handlingskompetanse i samspill med kolleger og brukergrupper kan avdekkes, og man står i fare for $\stackrel{a}{b l i}$ underkjent som fagautoritet hvis man ikke mestrer situasjonen (Goffman 1992, Sollund 2007, Daae-Qvale 2006, 2009, Ohnstad 2014).

En måte å kompensere for faglig utilstrekkelighet og opplevelse av ubehag på, kan være å skape rigide handlingsmønstre. Et rigid krav kan for eksempel være at forskjeller gjøres irrelevant i den forstand at alle brukere skal behandles likt, og at krav om å innrette seg etter helsevesenets premisser skjerpes overfor flerkulturelle brukergrupper. Kolleger som argumenterer mot en slik likhetstvang, blir ofte oppfattet som grenseoverskridere i den forstand at de bryter med forventede lojalitetskrav innad i profesjonsfeltet. En vanlig måte å signalisere grenseoverskridelse på, er gjennom uttalelser som «slik gjør vi ikke her», «slik gjør vi her» eller «du făr gi beskjed om at de făr innrette seg».

Krav om å etterkomme rigide handlingsmønstre blir ofte kommunisert gjennom bruk av «vi»-form. Når enkelte profesjonsutøvere ordlegger seg slik, gir de inntrykk av å snakke for hele praksisfeltet, selv om de målbærer en oppfatning som ikke har tilslutning fra alle deltagerne i fagfeltet. En slik bruk av «vi»-formen kan forstås som et redskap i en kamp for å monopolisere og legitimere kunnskap og praksis innenfor et felt (Bourdieu 1995), og er knyttet til definisjonsmakt i sosiale situasjoner og samhandling (Jørgensen og Phillips 1999, Grue 2011). Gjennom bruk av retorikk og definisjon av hvordan flerkulturell samhandling skal foregå, skaper enkelte profesjonsutøvere sterk dominans i miljøet, uten at de nødvendigvis har en formell lederrolle. Andre kolleger opplever dette som truende, og det er lett å komme i en avmaktssituasjon i møte med slik dominans. I kjølvannet av dette legges det samtidig lokk på kollegial frihet til åpen, kritisk refleksjon over profesjonens yrkesutøvelse. Kritisk refleksjon over egen profesjonsvirksomhet innebærer blant annet å se på seg selv som aktør i samspill med andre. Det handler om å kunne se hendelsen fra andres ståsted, og å kunne se hendelsen i kontekst. En annen forutsetning er å reflektere over hendelsen i et maktperspektiv og unders $\varnothing$ ke hvem som definerer hvilken sannhet som skal være gyldig (Grimen 2008, Heyerdahl-Larsen m.fl. 2014).

Til sist handler det om å se hendelsen i et verdiperspektiv, og i profesjonsutøvelse innebærer dette å følge yrkesetiske og faglige forpliktelser (Thorbjørnsrud 2008, HeyerdahlLarsen m.fl. 2014). Tradisjonelt har helsepersonell en verdibasert kompetanse, der blant annet solidaritet og vern av svake og marginaliserte grupper står sterkt. Helsepersonell utdannes til «å gjøre godt» og de trenes til å mestre ulike behandlingsbehov knyttet til akutte og kroniske lidelser. I tillegg skal de ivareta eksistensielle behov som berører livsløp fra fødsel til død. Helsepersonell som ikke evner å lindre eller behandle minoritetspasienter på en tilfredsstillende måte, gir uttrykk for manglende mestring i samspill mellom helsepersonell og pasienter/pårørende. Manglende mestring kan gi faglig utrygghet og medføre at helsepersonell unngår pasientene, eller overlater pasienter med minoritetsbakgrunn til andre kolleger. Ved å unngå eller overlate minoritetspasienters behandlingsbehov til andre, kan helsepersonell komme i konflikt med profesjonenes yrkesetiske retningslinjer.

Likeverdbegrepet er et grunnfestet behandlingsprinsipp i norsk helsevesen. Likeverdighet og rett til autonomi er to verdiladete begrep i profesjonsutøvelse (Eriksen 2001, Grimen 2008). Forståelse av likeverdighet gjennom tilpasset behandling synes å utfordre likhet som premiss, slik «det å gjøre likt» i mange fagfelt ofte er uttrykk for at profesjonsutøver handler rettferdig og solidarisk med brukergrupper. Ved å sette tilpasset behandling til side trues samtidig pasientens autonomi. Likeverdighet som ideal reflekteres ofte $\mathrm{i}$ en norsk kontekst som at alle skal behandles likt (Gullestad 2002). Når helsepersonell blir korrigert 
med at det å behandle likt faktisk kan undergrave behov for tilpasning, kan slike kritiske refleksjoner over praksis bli oppfattet som irettesettelse fra kolleger.

Kritisk refleksjon over praksis kan oppleves som kritikk av hele fagfeltet (Grimen 2008). Kritikken kan i verste fall fortolkes som kollegers moraliserende innspill i eget fagfelt. Noen studenter skriver at kolleger som våger å ytre kritiske refleksjoner over praksis, har opplevd å bli kalt illojale og blitt møtt med utestenging fra profesjonsfeltets faglige og sosiale fellesskap. Dersom diskusjon og refleksjon lammes ved at kollegiet ikke åpner opp for å diskutere profesjonsfeltets handlingskompetanse, er dette det samme som å legge lokk på faglig utvikling. Det å kunne pendle mellom ulike meningssystem og våge à håndtere lojalitetsutfordringer, er en nødvendig del av kritisk refleksjon over egen profesjonsutøvelse. Grimen (2008) hevder at dersom læring av feil forstås som kritikk av faglig virksomhet, bidrar profesjonene selv til å lukke praksis for endring og utvikling. Dette kan få konsekvenser for brukergrupper som har andre behandlingsbehov enn etablerte pasientgrupper. Brukere med flerkulturell bakgrunn har behov for å bli møtt ut fra egen virkelighetsforståelse. Det stiller krav til at helsepersonell evner å ta den andres ståsted $\mathrm{i}$ sin profesjonsutøvelse.

Studentenes tekster og erfaringer føyer seg inn i empiriske funn fra tidligere studier som beskriver gap mellom motivasjon for å fremme mangfoldsidealer i offentlig tjenesteyting på den ene siden, og motstand mot å implementere de samme idealer i praksis (Raaen 2003, Daae-Qvale 2006, 2009, Leseth og Solbække 2011, Sandbæk mfl. 20012, Rogstad og Solbrække 2012). Det som tekstene nyanserer, er hvordan manglende mestring i flerkulturelt samspill berører profesjonsidentitet i et faglig fellesskap. Når «det å gjøre godt» eller vise solidaritet med marginaliserte grupper ikke lykkes på grunn av manglende flerkulturell kompetanse, fordomsfulle og til tider diskriminerende holdninger i profesjonsfeltet, oppstår det motsetninger og paradokser i fagfeltet. Tekstene beskriver individuelt og kollektivt profesjonsansvar så vel som institusjonsstrukturer. De gir et helhetlig bilde av dynamikken som oppstår under pågående endringsprosesser i fagutviklingen i et profesjonsfelt. Dette er særlig aktuelt for fagkompetanse som ikke har høy status i yrkesfeltet, slik tilfellet synes å være for flerkulturell kompetanse (Raaen 2003, Daae-Qvale 2006, 2009, Sandbæk mfl. 2012).

\section{Flerkulturelle virkeligheter og profesjonell selvrefleksjon}

Studentene beskriver hvordan egenskaper som tillegges brukere med minoritetsbakgrunn er forbundet med hvorvidt brukergruppen tilpasser seg det behandlingstilbudet som praktiseres i profesjonsfeltet. En godt tilpasset flerkulturell brukergruppe blir ofte betegnet som complient. Innenfor medisin brukes ordet complience for à beskrive hvilken grad pasienten følger anvisninger gitt av helsepersonell (Ingstad 2007). Når brukere ikke følger behandlingsanvisning, blir de ofte beskrevet som non-compliente. Slike beskrivelser kan forstås som noe mangelfullt i pasientens evne til å forstå hvordan de skal oppføre seg, eller peke mot manglende vilje til å innrette seg. En student forteller om hvordan en kollega beskrev en hendelse i poliklinikken:

Jeg vet ikke hvor mange ganger jeg har stresset de fremmedkulturelle at de må komme presis. Men de vil jo ikke høre på oss. Vi kan ikke stå og vente til det passer Ahmed å komme. Det nytter ikke her, altså. Hvor mye skal vi tåle av den gruppa der? Jeg vil ikke ha det slik i min avdeling. De făr høre etter. De făr innrette seg i stedet for å teste våre grenser hele tiden. 
Det synes som om flerkulturelle brukergruppers annerledeshet skaper asymmetri i profesjonsfeltet ved at gruppen ikke er gjenkjennbar på sammen måte som norske pasienter, eller pasienter med flerkulturell bakgrunn som har tilpasset seg en norsk behandlingspraksis. Brukergruppens annerledeshet ser ut til à skape usikkerhet i profesjonshåndteringen. Studentene skriver at «profesjonsutøvere blir sentrert om egen frustrasjon» i møte med en brukergruppe de ikke greier å håndtere. Dermed oppstår en posisjonsforskyvningen som bringer profesjonsutøveren i sentrum snarere enn pasienten, noe som ikke er i tråd med en pasientsentrert forståelse - som er en sentral verdi i norsk helsevesen (Ingstad 2007). Profesjonsutøverne setter seg selv i fokus ved å tilkjennegi «at de får et problem» fordi «de må hanskes med et problem», slik som brukere med flerkulturell bakgrunn blir definert når de oppleves som non-compliente. Et paradoks i slike sammenhenger er at solidaritet og vern av svake grupper ikke finner sted fordi helsepersonell ikke greier «å gjøre godt» eller «handle til beste» for pasienter som ikke inngår i det definerte klassifikasjonssystemet.

Norsk utdannet helsepersonell er i sin yrkesrolle sosialisert inn i en naturvitenskapelig forklaringsmodell på helse, sykdom og behandling. Pasientens autonomi står sterkt, og tillit mellom helsepersonell og pasient er forankret i vissheten om overholdt konfidensialitet. I et norsk helselandskap kjenner stort sett både pasienter og helsepersonell «spillereglene» for samhandling mellom profesjonsutøver og pasient/pårørende. Når brukergrupper med annen kulturell bakgrunn trer inn i det norske helselandskapet, kommer ulike virkelighetsforståelser til uttrykk. Studenttekstene viser at den norske helsediskursen blir utfordret $\mathrm{i}$ møte med forskjellige sosiale verdensbilder slik de uttrykker seg gjennom andre kulturelle oppfatninger og forestillinger om helse, sykdom og behandling. Etablerte pasientkategorier og handlingsmønstre kan ikke lenger tas for gitt. Kontekster endres ved at helsepersonell skal samhandle med brukergrupper som gjennomgående representerer andre kommunikasjonsuttrykk for helsebehov enn hva profesjonsutøvere er vant med fra en norsk brukergruppe.

Norge som samfunn er bærer av egalitære verdier, slik disse kommer til syne i samfunnsinstitusjoner, utdanningssystem og fagfelt. I den norske velferdsstaten hvor likhetsideologien står sentralt, har større variasjoner i språklige, sosiale og kulturelle ferdigheter skapt nye betingelser for å forstå samhandling knyttet til likheter og forskjeller mellom majoritet og minoritet (Gullestad 2002, Lien m.fl. 2001). Når flerkulturell samhandling debatteres i offentlig sfære, er håndtering av likheter og forskjeller et tilbakevendende tema. Som regel er det tjenesteytere, gjennom majoritetens stemme, som avgjør når likheter og forskjeller skal gjøres relevante. Dette skjer også i profesjonsfeltet. En student skriver:

Som helsepersonell ønsker jeg å være en ressurs for alle pasienter, også de med innvandrerbakgrunn. Men det er ikke alltid så lett å løfte frem dette synet blant kolleger. Det å følge min egen overbevisning om at mange innvandrerpasienter har andre behandlingsbehov enn de norske har ført til ubehagelige kommentarer fra enkelte kolleger. Jeg hører ofte: Du kan ta deg av disse fremmedkulturelle siden du interesserer deg spesielt for denne gruppen. Jeg blir jo stående alene da og det er ikke akkurat noen god følelse å bli avspist med at jeg kan ta ansvar for pasienter som de andre kollegene sier at de ikke skjønner seg på.

Møter med flerkulturelle brukergrupper blir blant enkelte profesjonsutøvere opplevd som problemfylt. Studentene beskriver at brukere med minoritetsbakgrunn ofte blir definert gjennom negativt ladete kategorier knyttet til religion, kultur og etnisitet. I tekstene omtales også brukere med minoritetsbakgrunn gjerne gjennom kategorier av «de», «disse» 
og «fremmedkulturelle» - kategorier som alle uttrykker ulike former for avstand og generaliseringer. En student gjengir en kommentar som ofte går igjen i møte med minoritetspasienter: «De fremmedkulturelle provoserer meg. Hvordan kan vi hjelpe noen som ikke skjønner hva vi holder på med?» En annen student beskriver hvordan stereotype og diskriminerende holdninger kommer til uttrykk gjennom følgende utsagn: «Jeg er lei av kulturen deres. Mennene styrer alt, og damene sier ingenting. Det er ikke slik det fungerer $\mathrm{i}$ samfunnet vårt.» Nyanser som kunne si noe om den enkelte brukers integritet og identitet forsvinner gjennom en slik omtale, noe som kan få negative konsekvenser for kvaliteten på helsetilbudet til disse tjenestebrukerne. (Eide m.fl. 2009, Gullestad 2002).

Tekstene viser at helsepersonell som av ulike grunner ikke mestrer håndtering av flerkulturelle problemstillinger, eller som har fordomsfulle eller diskriminerende holdninger til flerkulturelle brukergrupper, ofte gir uttrykk for dette gjennom negativ og problemfylt språkbruk. Brukere med minoritetsbakgrunn blir omtalt gjennom andregjøring, der kulturelle, etniske og religiøse praksiser blir redusert til noe av mindre verdi enn majoritetens væremåte (Said 1994). Gjennom slik negativ språkbruk skapes det samtidig en «sannhet» om flerkulturelle brukergrupper i helsevesenet. I et diskursanalytisk perspektiv kan etablering av denne sjangerformen forstås som at noen i profesjonsfeltet tar definisjonsmakt over hva som skal være gyldig fortolkning og kunnskap om minoritetsgruppers egenskaper. Negative forestillingene om innvandrere blir i denne sammenhengen den verdien som skal ha forrang fremfor andre fortolkninger av innvandrere, og er i tråd med det som beskrives som kampen om posisjoner i et avgrenset felt. Posisjonering kan også forstås som makt til å definere hvilken sannhet som skal være gyldig i omtale av enkelte brukergrupper. Dette kan bidra til stigmatisering av flerkulturelle brukergrupper. De blir fortolket som avvikende fra en norsk brukergruppe, og en konsekvens kan bli at gruppen ved ikke «å oppføre seg riktig» blir marginalisert og ikke får oppfylt sine helsebehov tilstrekkelig. Studentene beskriver videre at når de selv eller andre kolleger tar til motmæle mot fordomsfulle og diskriminerende forestillinger og ytringer, så oppstår det spenninger i kollegiet. Spenningene kan enten medføre at kolleger med korrigerende innspill blir ignorert, eller i verste fall bli møtt med ekskluderende handlinger. Noen studenter beskriver også at det å omtale minoritetsgrupper negativt ofte blir bagatellisert og vridd på: «Ærlig talt, ikke bli så hårsår på disses vegne da, det må da være lov å spøke litt om Ahmed og Fatima». Språkbruk og holdninger knyttet til minoriteter synes klart å utfordre profesjonsidentiteter i profesjonsfellesskapet. Dette kan tyde på at det hersker klare forestillinger om at det å ikke tenke og handle likt kan skape uro og utfordringer innad i et forestilt faglig fellesskap.

Norske helseinstitusjoner kan på mange måter forstås som monokulturelle i den forstand at diagnostisering og behandling springer ut av en norsk og vestlig helsediskurs. I Norge er statlige institusjoner kvalifiseringsarenaer for helse, og myndighetene har definert hvilke helsegevinster som skal gjelde for befolkningen.

Forvaltning av velferd er ikke utelukkende uproblematisk (Eriksen 2001). Bruk av spesialisert kunnskap, monopolisering og bruk av skjønn kan i enkelte sammenhenger også medføre at beslutninger fattes på feil grunnlag fordi profesjonene ikke har tilstrekkelig kunnskap om brukergrupper. Brukergrupper med flerkulturell bakgrunn vil som oftest bære andre kulturelle uttrykk for helse sykdom og behandling enn de helseuttrykk som majoritetsbefolkningen i Norge speiler. En økende innvandrerbefolkning kan bli sårbar i kraft av å bære med seg andre livsforståelser enn en tilpasset og disiplinert majoritet.

Flerkulturell kompetanse skal bidra til at blant annet helsepersonell gjennom utdanning tilegner seg kunnskaper og ferdigheter til å reflektere og håndtere egen og andres virkelighetsforståelse $\mathrm{i}$ et flerkulturelt samspill. Et særtrekk ved mange offentlige 
institusjoner som i dag målbærer likeverd og mangfold, er at det ikke har foregått gjennomgripende felles diskusjoner om hva det flerkulturelle aspektet ved institusjonene skal innebære (Raaen 2002, Daae-Qvale 2006, 2009, Sandbæk m.fl. 2012, Rogstad m.fl. 2012). Med bakgrunn i dette uteblir ofte en felles faglig og organisatorisk forståelse av hvordan etablert profesjonspraksis ( $i$ en norsk vestlig organisasjonsmodell) skal møte og håndtere en flerkulturell brukergruppe. En student beskriver dette dilemmaet slik:

Erfaring fra mitt arbeidssted sier meg at interessen for flerkulturell fagutvikling er veldig variert blant mine kollegaer. Ofte hører man sukk og oppgitthet, og lite forståelse over flerkulturelle brukeres problemer. Når jeg skal på samling er det ikke alltid jeg har store forventninger. Det er ikke studiet, men arbeidsstedet mitt som begrenser disse. Jeg føler meg litt «alene», ingen er spesielt opptatt av dette, og noen ganger har jeg dårlig samvittighet for å være borte i tre, fire dager, da jeg vet at det står på hodet $\mathrm{i}$ avdelingen. Selv om jeg har fătt innvilget permisjon føler jeg det slik.

Når pasienter med minoritetsbakgrunn i kraft av forskjellighet håndteres som problematiske, oppfyller ikke helsepersonell målsettingen om likeverdighet i behandling. Det å bli stående alene med et flerkulturelt fagansvar beskrives av studentene som tap av faglig fellesskap i profesjonsmiljøet, og uttrykkes som «å bli latt i stikken» med sin nyervervete kompetanse. I møte med minoritetspasienter utfordres ikke helsepersonell bare på hvordan de skal forstå pasientenes kulturelle bakgrunn. En like viktig bevisstgjøring er hvordan helsepersonell som majoritetsgruppe evner å forstå egne samfunnsverdier, så vel som de strukturelle og organisatoriske forholdene helsevesenet fungerer gjennom.

\section{Avsluttende kommentarer}

Krav om likeverdighet i etnisk likestillingsarbeid kan knyttes til velferdsstatens integreringsmål der likhetsidealet og forestillinger om likhet bidrar til et sterkt normaliseringspress. Normaliseringspresset gjenspeiles i en institusjonell retorikk der «det norske» i høy grad fremstår som målestokk for å regulere og justere atferd - dette gjelder også for brukere med flerkulturell bakgrunn. Den norske enhetskulturen synes å komme i konflikt med politiske målsettinger om å tolerere og anerkjenne kulturelle forskjeller gjennom tilpasset behandling. Håndtering av mangfold $i$ helsevesenet forutsetter at helsepersonell har kunnskap og innsikt $\mathrm{i}$ kultursensitive problemstillinger. Et av myndighetenes virkemidler for å styrke flerkulturell kompetanse i offentlig sektor er utdanning. Konsekvensene av å ignorere dette kompetansekravet kan bli at flerkulturelle brukergruppers helsebehov og erfaringer ikke blir kjent. Samtidig kan ignorering av flerkulturelle problemstillinger $\mathrm{i}$ helsevesenet legge lokk på åpne, offentlige diskusjoner om helseprofesjonenes ansvar i etnisk likestillingsarbeid. Ved ikke à stille krav om flerkulturell kompetanse hos helsepersonell vil konflikten mellom rett til forskjellighet på den ene siden og krav om likhet på den andre siden således kunne forbli uløst. 


\section{Referanser:}

Barth, F. (1994). Manifestasjon og prosess. Oslo: Universitetsforlaget.

Bourdieu P. (1995). Distinksjonen: En sosiologisk kritikk av dømmekraften. Oslo: Pax.

Båtnes, P.I. (2006). ̊ forvalte sin kunnskap i kulturelt utsatte posisjoner - om formidling av frimodighet. I: Greek, Jonsmoen (Red). Utfordringer i flerkulturell formidling. Oslo: HiO-rapport nr. 30.

Daae-Qvale, I. (2006). Ønske det, ville det - gjøre det med: Om forankring av flerkulturell kompetanse i offentlig sektor. I: Greek, Jonsmoen (Red). Utfordringer i flerkulturell formidling. Oslo: HiO-rapport nr. 30.

Daae-Qvale, I. (2009). Minoritetselever i videregående skole - ressursorientering, usynliggjøring og problemfokus I: Eide, K., Qureshi, N., Rugkåsa, M., Vike, H. (Red). Over profesjonelle barrierer. Et minoritetsperspektiv i psykososialt arbeid med barn og unge. Oslo: Gyldendal Akademisk.

Eide, K., Qureshi, N., Rugkåsa, M., Vike, H. (Red). (2009) Over profesjonelle barrierer: Et minoritetsperspektiv i psykososialt arbeid med barn og unge. Oslo: Gyldendal Akademisk.

Eriksen, E.O. (2001). Demokratiets sorte hull: Om spenning mellom fag og politikk i velferdsstaten. Oslo: Abstrakt. http://dx.doi.org/10.1080/000164701753542041

Fairclough, N. (1992a). Discourse and Social Change. Cambridge: Polity Press.

Foucault, M. (1999). Diskursens orden. Oslo: Spartacus.

Goffmann, E. (1992). Vårt rollespill til daglig. Oslo: Pax Forlag.

Grimen, H. (2008). Profesjon og kunnskap. I: Molander, A., Terum, L.I. (Red). Profesjonsstudier. Oslo: Universitetsforlaget.

Grue, J. (2011). Maktbegrepet i kritisk diskursanalyse: Mellom medisinske og sosiale forståelser av funksjonshemming. I: Hitching, T.R., Nilsen, A.B., Veum, A. (Red.): Diskursanalyse i praksis: Metode og analyse. Kristiansand: Høyskoleforlaget.

Gullestad, M: (2002). Det norske sett med nye øyne. Oslo: Universitetsforlaget.

Hansbøl, G., Krejsler, J. (2004). Konstruktion af professional identitet - en kulturkamp mellem styring og autonomi i et markedssamfund. I: Moos, L. m.fl. (Red.):

Relationsprofessioner. København: Danmarks Pædagogiske Universitets Forlag.

Heggen, K. (2008). Profesjon og identitet. I: Molander, A., Terum, L.I. Profesjonsstudier. Oslo: Universitetsforlaget.

Heyerdahl-Larsen, J., Popova, B., Obilie, J. (2014). A møte ubehaget med kritisk refleksjon. I: Ohnstad, A., Rugkåsa, M., Ylvisaker, S.(Red.). Ubehaget i sosialt arbeid. Oslo: Gyldendal Akademisk.

Hitching, T.R., Nilsen, A.B., Veum, A. (Red.). (2011). Diskursanalyse i praksis: Metode og analyse. Kristiansand: Høyskoleforlaget.

Hitching, T.R., Veum, A. (2011). Introduksjon. I: Hitching, T.R., Nilsen, A.B., Veum, A. (Red.). Diskursanalyse i praksis: Metode og analyse. Kristiansand: Høyskoleforlaget.

Ingstad, B. (2007). Medisinsk antropologi: En innføring. Bergen: Fagbokforlaget.

Jørgensen, M.W., Phillips, L. (1999). Diskursanalyse som teori og metode.

Samfundslitteratur. Frederiksberg: Roskilde Universitetsforlag.

Kumar, B., Viken, B. (Red). (2010). Folkehelse $i$ et migrasjonsperspektiv. Bergen: Fagbokforlaget.

Leseth, A., Solbæekke, A. K. N. (Red). (2011). Profesjon, kjønn og etnisitet. Latvia: Cappelen Damm Aklademisk. 
Lien, M.E., Lidén, H., Vike, H. (Red.). (2001). Likhetens paradokser: Antropologiske undersøkelser $i$ det moderne Norge. Oslo: Universitetsforlaget.

Molander, A, Terum, L.I. (2008). Profesjonsstudier - en introduksjon. I: Molander A, Terum L.I. (Red). Profesjonsstudier. Oslo: Universitetsforlaget.

Nasjonal strategi om innvandreres helse 2013-2017. (2013). Likeverdige helse- og omsorgstjenester - god helse for alle, Helse- og omsorgsdepartementet.

Ohnstad, A. (2014). Ubehaget som kunnskapskilde. I: Ohnstad, A., Rugkåsa, M., Ylvisaker, S. (2014) (Red.). Ubehaget i sosialt arbeid. Oslo: Gyldendal Akademisk.

Raaen, F.D., (Red). (2002). Evalueringsrapport om Videreutdanning i flerkulturell forståelse. Oslo: Høgskolen i Oslo.

Rogstad, J., Solbrække, K.N. (2012). Velmenende likegyldighet. Konflikt og integrasjon i et flerkulturelt sykehus. I: Sosiologisk tidsskrift, volum 12(1), 315-338.

Said, E. (1994.) Orientalismen. Oslo: Cappelen

Sandbæk, M.L., Hjelde, I., Rogstad, R.(2012): Det står mye på spill: En evaluering av Videreutdanning i veiledning i flerkulturelt helsearbeid. Oslo: Fafo.

Scollon, R., Scollon, S., Jones, H.R. (2012). Intercultural Communication. A Discourse Approach. 3.ed. Oxford: Blackwell Publishers Ltd.

Slagstad, R. (2008). Profesjoner og kunnskapsregimer. I: Molander A, Terum L.I. (Red). (2008). Profesjonsstudier. Oslo: Universitetsforlaget.

Sollund, R. (2007). Tatt for en annen. Oslo: Gyldendal Akademisk.

Stortingsmelding nr.17. (1996-97). Om innvandring og det flerkulturelle Norge

Stortingsmelding nr. 49. (2003-2004). Mangfold gjennom inkludering og deltakelse.

Stortingsmelding nr. 6. (2012-2013). En helhetlig integreringspolitikk. Mangfold og fellesskap

Thorbjørnsrud, B. (2008). Kritikk av relativismekritikken. I: Samtiden, 1-2008, 96-104. Oslo: Aschehoug.

Vike, H. (2001). Anonymitet og offentlighet. I: Norsk antropologisk tidsskrift, volum 12 (1-2), 76-84.

Østby L., E. Høydahl og Ø. Rustad. (2013). Innvandrernes fordeling og sammensetning på Kommuneniva. SSB. Rapport 2013/37 